\title{
Solid-phase micro-extraction (SPME) in the early detection of potentially active volatile compounds from organic wastes used for the management of soil-borne pathogens
}

\author{
ESTHER DE LA FUENTE ${ }^{1}$, ANA C. SORIA ${ }^{1}$, MIGUEL A. DÍEZ-ROJO ${ }^{2}$, ANA PIEDRA \\ BUENA $^{2}$, AVELINO GARCÍA-ÁLVAREZ ${ }^{3}$, GONZALO ALMENDROS ${ }^{2 *}$ and \\ ANTONIO BELLO ${ }^{2}$ \\ ${ }^{1}$ Instituto de Química Orgánica General (CSIC), Madrid, Spain. \\ ${ }^{2}$ Centro de Ciencias Medioambientales (CSIC), Madrid, Spain. \\ ${ }^{3}$ Centro de Investigaciones Energéticas, Medioambientales y Tecnológicas, Madrid, Spain.
}

\begin{abstract}
The complex molecular assemblages were analysed in the soil gas phase after applying pine forest wastes (PFW) or sugarbeet vinasses (SBV) for soil-borne crop pests management. For this purpose, solid-phase micro-extraction (SPME) and gas chromatography (GC) were used coupled with mass spectrometry (MS). The organic wastes were applied either to Calcic Entisol or Haplic Arenosol moistened at field capacity and soil was covered with polyethylene sheet for 28-30 days to retain the volatiles. The PFW-treated soil mainly released volatile terpene hydrocarbons (trans-caryophyllene, $\beta$-myrcene and $p$-cymene), with $\alpha$-humulene and ethylbenzotriazole prevailing in the untreated soil. After SBV application mainly alkyl compounds and alkylbenzenes were released, whereas cyclohexanone, limonene, butanone, acetic acid, camphor and benzaldehyde occurred in the untreated soil. Compound assemblages also depended on the increasing water saturation in terms of soil depth, with sulphur compounds prevailing in deep horizons. Our results showed that SPME can be directly applied to soils to provide valuable information on volatile products from organic amendments.
\end{abstract}

Keywords: Biodisinfestation, biofumigation, compost, forest waste, gas phase, pine litter, sugarbeet vinasses.

\section{INTRODUCTION}

Gas chromatography coupled with mass spectrometry (GC-MS) is the most frequently used technique in the analysis of complex mixtures of organic volatile compounds. However, this requires their previous isolation from the non-volatile components of the sample. On the other hand, solid phase microextraction (SPME) is a simple, rapid and non-expensive technique which allows the fractionation of the volatiles released from liquid and solid samples. ${ }^{[1]}$ Such a technique, which has been mainly used in the analysis of food and in the monitoring of environmental pollution, ${ }^{[2,3]}$ could also be useful in other areas, such as agricultural chemistry. However, to date, its application in the analysis of natural volatile products in the soil gas phase has been very scarce, and usually directed towards the determination of pollutants. ${ }^{[4]}$ Volatile organic compounds have recently been analyzed by SPME in marine sediments ${ }^{[5]}$ and in waste disposal landfills. ${ }^{[6]}$

\footnotetext{
*Address correspondence to Gonzalo Almendros, Soils Dept., Centro de Ciencias Medioambientales (CSIC), Serrano 115B, 28006 Madrid, Spain. Phone: +34-917452500 ext. 220; Fax: +34-915640800; E-mail: humus@ccma.csic.es or a.piedrabuena@ccma.csic.es

Received December 30, 2008. Accepted March 25, 2009.
} 
Biofumigation or biodisinfestation ${ }^{[7-11]}$ has been proposed as a valid alternative to the use of agrochemicals for the control of plant pests. ${ }^{[12-14]}$ In particular, pest management based on the release of volatile compounds from organic wastes has been successful for several pathogenic organisms. ${ }^{[15]}$ Nevertheless, no extensive research has been developed to unravel the chemical nature of the volatile compounds responsible for the beneficial effects of biodisinfestation practices. Yulianti et al., ${ }^{[16]}$ in experiments on the simultaneous use of a polyethylene sheet on soil (solarization or biosolarization) to retain the volatiles, highlighted the importance of sulphur compounds released from decaying Cruciferae and Compositae plants for controlling some soil pathogens. Biosolarization usually leads to a considerable enhancement of the organic matter biocidal effect on the soil pathogens, through increased topsoil temperature and concentration of bioactive compounds. Also, this practice may also lead to remarkable changes in the prevalence patterns within the different trophic groups of the soil macro- and microfauna. ${ }^{[17]}$

On the other hand, the molecular assemblages with a bearing on the success of the biodisinfestation process have shown to be to a large extent dependant on the organic source used in each case. ${ }^{[14]}$ Although the effect of some compounds such as isothiocyanates, glucosinolates and nitriles has been highlighted ${ }^{[12,18-22]}$ no systematic studies have been carried out on the determination of other volatile compounds released after the addition of organic materials to the soil. It must also be taken into account the need to assess the potential of organic materials used for soil biodisinfestation as soil and water pollutants, as well as the possibility of using them to improve soil fertility or for the control of soil-borne pathogens. Assuming the above considerations, this paper focuses on the identification of the compounds occurring in the gas phase after soil amendment with pine forest wastes (PFW) and sugarbeet (Beta vulgaris L.) vinasses (SBV). The results of both experiments in laboratory conditions are presented evaluating SPME followed by GC-MS for the detection of soil volatiles.

\section{MATERIAL AND METHODS}

\section{Experimental Design}

Organic materials were selected mainly based on their large and concentrated production in time and space, which poses a problem on their non-hazardous disposal and raises the interest of finding further environmentally-friendly uses for them. In urban green areas (mainly public gardens) of the Mediterranean areas, PFW is common organic waste, whereas sugarbeet vinasses (SBV) are a common liquid by-product from the Spanish sugar industry.

Both experiments were carried out in laboratory conditions. The first experiment was carried out on Calcic Entisol from Játiva, Alicante (Eastern Spain), a shallow, calcic, poorly developed soil without definite horizons, and of a coarse texture, with a $\mathrm{pH}$ of 7.8 , and an organic matter content of $17 \mathrm{~g} \cdot \mathrm{kg}^{-1}$. The added organic material was PFW (Pinus halepensis Mill.) from municipal gardens at Jávea (Alicante, Spain), consisting of chopped $( \pm 1 \mathrm{~cm})$ needles $(83 \%)$ and thin branches (17\%), with dry matter content of $50.6 \%$ (Table 1$)$. The PFW were mixed at 20 and $40 \mathrm{~g}$ per $\mathrm{kg}$ soil, corresponding to an input equivalent to 50 and $100 \mathrm{Mg} \mathrm{PFW} \cdot \mathrm{ha}^{-1}$, in polyethylene bags containing $0.5 \mathrm{~kg}$ soil each. After soil moistening at field capacity, polyethylene bags were completely sealed and kept at $30 \pm 2^{\circ} \mathrm{C}$, in darkness, for 28 days. A control treatment without the application of organic matter was included (PFW control). There were four replications of each treatment. 
Table 1. Characterization of pine forest wastes (PFW) and sugarbeet vinasses (SBV)

\begin{tabular}{lrr}
\hline & PFW & \multicolumn{1}{c}{ SBV } \\
\hline Organic matter $\left(\mathrm{g} \cdot \mathrm{kg}^{-1}\right)$ & 965 & 284 \\
Conductivity $\left(\mu \mathrm{S} \cdot \mathrm{cm}^{-1}\right)$ & 1673 & 14620 \\
$\mathrm{~N}\left(\mathrm{~g} \cdot \mathrm{kg}^{-1}\right)$ & 14 & 29 \\
$\mathrm{Ca}\left(\mathrm{mg} \cdot \mathrm{kg}^{-1}\right)$ & 5634 & 2510 \\
$\mathrm{Cu}\left(\mathrm{mg} \cdot \mathrm{kg}^{-1}\right)$ & 8.5 & 7.2 \\
$\mathrm{Fe}\left(\mathrm{mg} \cdot \mathrm{kg}^{-1}\right)$ & 388 & 19 \\
$\mathrm{~K}\left(\mathrm{mg} \cdot \mathrm{kg}^{-1}\right)$ & 4963 & 3400 \\
$\mathrm{Mg}\left(\mathrm{mg} \cdot \mathrm{kg}^{-1}\right)$ & 1267 & 6708 \\
$\mathrm{Mn}\left(\mathrm{mg} \cdot \mathrm{kg}^{-1}\right)$ & 7 & 18 \\
$\mathrm{Na}\left(\mathrm{mg} \cdot \mathrm{kg}^{-1}\right)$ & 67 & 22000 \\
$\mathrm{P}\left(\mathrm{mg} \cdot \mathrm{kg}^{-1}\right)$ & 1467 & 2985 \\
$\mathrm{~Pb}\left(\mathrm{mg} \cdot \mathrm{kg}^{-1}\right)$ & $<5$ & $<5$ \\
$\mathrm{Zn}\left(\mathrm{mg} \cdot \mathrm{kg}^{-1}\right)$ & 227 & 27.5 \\
\hline${ }^{\mathrm{a}} 1: 10 \mathrm{w}: \mathrm{v}(\mathrm{soil}:$ water $)$ & &
\end{tabular}

The second experiment was carried out on Haplic Arenosol (Jumilla, Murcia, in the Spanish South-East), a characteristic soil in the area of SBV production, with a sandy-loam upper horizon ( $85 \%$ sand and 6-7\% clay), 10\% carbonates, $\mathrm{pH} 7.9$, and an organic matter content of $2.5 \mathrm{~g} \cdot \mathrm{kg}^{-1}$. The SBV (50\% dry matter, Table 1), from the Castile-La Mancha region, was applied at a dose of $187 \mathrm{~g}$ per $\mathrm{kg}$ soil, corresponding to an input equivalent to 25 $\mathrm{Mg} \mathrm{SBV} \cdot \mathrm{ha}^{-1}$. The experiment was performed in methacrylate cylinders $(15 \mathrm{~cm}$ diameter $\times 1$ $\mathrm{m}$ high) filled with $36 \mathrm{~kg}$ soil. The cylinders were sealed with a polypropylene cover and kept at $24 \pm 2{ }^{\circ} \mathrm{C}$ for 30 days. A control treatment without an organic matter application was included (SBV control). There were four replicates (columns) of each treatment. Since the inherent problem of liquid wastes to behave as a leachate when used as a soil amendment, the experiment was specifically designed to check the vertical distribution of the organic matter in terms of soil depth. In consequence, samples were collected from different depths in the metacrylate columns, i.e. $20 \mathrm{~cm}$ (sample No. 1), $40 \mathrm{~cm}$ (sample No. 2), $60 \mathrm{~cm}$ (sample No. 3) and $80 \mathrm{~cm}$ (sample No. 4). The SBV gas phase composition was also analysed and also labelled as SBV organic waste.

\section{Solid-Phase Micro-Extraction Analyses}

Preliminary experiments were carried out in the PFW experiment with up to five replicates. The same five major components appeared in all the runs, but the relative (\%) standard deviation of their concentrations was in the range 30.4-47.0 for such compounds. The results led us to focus our study in the SPME potential assessment of qualitative fingerprinting of the volatiles present in the gas phase for the soil samples processed under the same conditions. The chromatogram profile obtained by SPME fractionation could then be related to changes in the soil microfauna. A quantitative analysis was not intended, the relative abundance being marked by one to three asterisks.

At the end of the biodisinfestation experiment (28 days for PFW and 30 days for SBV) each replicate was homogenized by mixing the soil thoroughly. Approximately $1 \mathrm{~g}$ soil was 
collected from each replicate, introduced into $4 \mathrm{~mL}$ glass vials and adding $1 \mathrm{~mL}$ of Milli-Q${ }^{\circledR}$ of water. Soil samples were homogenized by stirring, and vials were sealed with predrilled septa. For headspace sampling, a manual SPME holder equipped with an $85-\mu \mathrm{m}$ Carboxen/polydimethylsiloxane StableFlex fibre (both from Supelco Co. Bellefonte, PA). This fibre was chosen on the basis of the wide range of polarity for the volatile compounds occurring in the compost gas phase (ranging from between acetic acid and other short-chain alkanoic acids to hydrocarbons) observed in preliminary experiments. ${ }^{[23]}$ In similar previous experiments with this fibre, the equilibrium time and temperature were reached at values similar to the optimum (maximum amount of volatiles extracted and minimum artifact formation) for other organic substrates, such as food products. The fibre was conditioned at the manufacturer's recommended temperature before the analysis, then the vials were kept at $60{ }^{\circ} \mathrm{C}$ for $15 \mathrm{~min}$ (equilibrium time) before exposing the fibre to the soil headspace (injector temperature $=250{ }^{\circ} \mathrm{C}$ ) for $30 \mathrm{~min}$. Under the above conditions the qualitative chromatographic patterns were the same, and the quantitative differences in peak areas were reasonably reproducible.

\section{Gas Chromatographic-Mass Spectrometric Analyses}

The GC-MS analyses were performed on an Agilent 6890 (Palo Alto, CA, USA) gas chromatograph coupled with an Agilent 5973 quadrupole mass detector. The SPME fibre was desorbed at $250{ }^{\circ} \mathrm{C}$ for $2 \mathrm{~min}$ in the splitless mode and chromatographic separation was carried out on a $50 \mathrm{~m} \times 0.25 \mathrm{~mm} \times 0.25 \mu \mathrm{m}$ polyethyleneglycol capillary column (Supelcowax-10, Supelco ${ }^{\circ}$, Bellefonte, PA). The oven temperature was programmed from $40{ }^{\circ} \mathrm{C}(2 \mathrm{~min})$ to $190{ }^{\circ} \mathrm{C}(30 \mathrm{~min})$ at $4{ }^{\circ} \mathrm{C} \mathrm{min}{ }^{-1}$. Helium at $1 \mathrm{~mL} \mathrm{~min}^{-1}$ was used as a carrier gas. The mass spectra were recorded in electron ionization (EI) mode at $70 \mathrm{eV}$, by scanning the $35-450 \mathrm{~m} / \mathrm{z}$ range. Interface and source temperature were 280 and $230{ }^{\circ} \mathrm{C}$, respectively. Compounds identifications were based on comparisons of the spectra obtained with those of the NIST and Wiley mass spectral libraries ${ }^{[24,25]}$ and were confirmed, when possible, using programmed temperature Kovats indices determined from the retention times of an $n$-alkane mixture analyzed under identical conditions. Available standard compounds were also used for further confirmation.

\section{RESULTS AND DISCUSSION}

Tables 2 and 3 list the volatile organic compounds identified by SPME followed by GC-MS in both experiments. Unidentified compounds represented $15 \%$ of the chromatographic area. The repeated determinations systematically showed the same compounds, but their relative abundance varied around 30\%. This systematic variation between repetitions suggested the transformation of the results into standardized indices indicated with $\times, \times \times$, and $x \times x$. Therefore, the results presented for each compound are not significantly $(P<0.05)$ affected by the extent of the variation between repetitions of the same sample. 
Table 2. Tentative identification of organic volatiles released from soils treated with pine forest waste (PFW)

\begin{tabular}{|c|c|c|c|c|c|}
\hline \multirow[b]{2}{*}{ MW } & \multirow[b]{2}{*}{ Compound } & \multicolumn{2}{|c|}{ Dose $\left(\mathrm{PFW} \cdot \mathrm{kg} \mathrm{soil}{ }^{-1}\right)$} & \multirow[t]{2}{*}{ Control } & \multirow[t]{2}{*}{$\begin{array}{l}\text { Pine forest } \\
\text { waste }\end{array}$} \\
\hline & & $20 \mathrm{~g}$ & $40 \mathrm{~g}$ & & \\
\hline 72 & Butanone & $x$ & $x$ & & \\
\hline 111 & Trimethylcyclohexanone & & & $x$ & \\
\hline 126 & Dimethylheptene & & & $x$ & \\
\hline 128 & Dimethylheptane & & & $x$ & \\
\hline 134 & $p$-cymene & $x \times x$ & $x \times x$ & & $x \times x$ \\
\hline 136 & $\alpha$-pinene & $x x$ & $x$ & $x$ & $x x$ \\
\hline 136 & Dimethyloctadiene & $x x$ & $x$ & $x$ & $x$ \\
\hline 136 & $\alpha$-terpinene & $x$ & & & $x$ \\
\hline 136 & Dimethyloctatriene & $x x$ & & & $x$ \\
\hline 136 & $\beta$-myrcene & $x x x$ & $x x$ & $x$ & $x x$ \\
\hline 136 & Limonene & $x$ & $x x$ & & $x$ \\
\hline 136 & $\alpha$-terpinolene & $x x x$ & $x$ & $x$ & $x x$ \\
\hline 38 & Methylbutylidene-cyclopentane & $x x x$ & $x x$ & & $x x$ \\
\hline 140 & Dimethyloctene & $x$ & $x$ & & \\
\hline 147 & Ethylbenzotriazole & $x$ & $x$ & $x x$ & \\
\hline 204 & Trans-caryophyllene & $x x x$ & $x x x$ & $x$ & $x \times x$ \\
\hline 204 & $\alpha$-humulene & $x x$ & $x \times x$ & $x \times x$ & $x x$ \\
\hline
\end{tabular}

Semiquantitative data of peak areas calculated as relative abundances are shown as standardized indices: $x=0-33 \%, x x=34-66 \%$, and $x x x=67-100 \%$.

In the gas phase of the untreated soil of the PFW experiment more than 50 alkanes were detected, the main compounds identified being branched alkanes and alkenes with between 11 and 15 carbon atoms and ethylbenzotriazole (Table 2). These compounds could have an anthropogenic origin, e.g. fuel combustion residues from vehicles or agricultural machinery. ${ }^{[26]}$ Some mono- and sesquiterpenes were also present, but only in low amounts. On the other hand, in the treated soil gas phase, mono- and sesquiterpenes appeared in higher concentrations, trans-caryophyllene, $\beta$-myrcene, $p$-cymene, $\alpha$-humulene and $\alpha$-terpinolene being the most important compounds identified. Branched alkanes and ethylbenzotriazole were present in relatively low amounts. Since terpenes are systematic components of pine needles, ${ }^{[27-32]}$ there were expected to occur in PFW-amended soils. However, the relatively high amount of $\alpha$-humulene detected both in treated and non-treated soils suggests an origin other than pine needles. As some authors have mentioned this compound being present in a wide range of plants such as hop, ${ }^{[33,34]}$ maize, ${ }^{[35]}$ pasture, ${ }^{[36]}$ and several Mediterranean spices, ${ }^{[37]}$ their occurrence in soils is expected to be frequent. 
Table 3. Tentative identification of organic volatiles released from soils treated with sugarbeet vinasses (SBV)

\begin{tabular}{|c|c|c|c|c|c|c|c|}
\hline \multirow[b]{2}{*}{ MW } & \multirow[b]{2}{*}{ Compound } & \multicolumn{4}{|c|}{ Sample No. } & \multirow[b]{2}{*}{ Control } & \multirow[b]{2}{*}{$\begin{array}{c}\text { Sugarbeet } \\
\text { vinasses }\end{array}$} \\
\hline & & $\begin{array}{c}1 \\
20 \mathrm{~cm}\end{array}$ & $\begin{array}{c}2 \\
40 \mathrm{~cm}\end{array}$ & $\begin{array}{c}3 \\
60 \mathrm{~cm}\end{array}$ & $\begin{array}{c}4 \\
80 \mathrm{~cm}\end{array}$ & & \\
\hline 58 & Propanone & & & & & & $x$ \\
\hline 60 & Acetic acid & $x x$ & & & $x x$ & $x$ & $x \times x$ \\
\hline 62 & Dimethylsulfide & & & $x x$ & & & $x$ \\
\hline 72 & Butanone & & $x$ & $x$ & $x x x$ & $\times$ & $x$ \\
\hline 74 & Propanoic acid & & & & $x x$ & & \\
\hline 76 & Carbon sulfide & & & $x x$ & & & \\
\hline 82 & Methylfuran & & $x$ & & & & $x$ \\
\hline 83 & Methylbutanenitrile & & & & & & $x$ \\
\hline 84 & Methylbutanal & & & $x$ & & & $x$ \\
\hline 84 & Dichlorometane & & & $x$ & & & \\
\hline 86 & Methylbutanal & & & $x$ & & & $x$ \\
\hline 86 & Dihydro-2- $(3 H)$ furanone & $x x$ & & & & & \\
\hline 86 & Terpene compound & & $x$ & $x$ & & & \\
\hline 88 & Methylpropanoic acid & & & & $x$ & & \\
\hline 88 & Butanoic acid & & & & & & $x x$ \\
\hline 90 & Butanediol & & & & & & $x x$ \\
\hline 92 & Methylbenzene (toluene) & $x x x$ & $x$ & & & & \\
\hline 94 & Phenol & & & & $x$ & & \\
\hline 94 & Dimethyldisulfide & & & $x x$ & & & \\
\hline 98 & Cyclohexanone & $x x$ & & & & $x \times x$ & \\
\hline 100 & Cyclohexanol & $x x$ & & & & & \\
\hline 103 & Nitrobutane & & $x x$ & $x$ & & & \\
\hline 103 & Benzonitrile & & $x$ & & & & \\
\hline 104 & Styrene & $x x$ & & & & & \\
\hline 106 & Dimethylbenzenes (xylenes) & $x x$ & & & & & \\
\hline 106 & Ethylbenzene & $x$ & & & & & \\
\hline 106 & Benzaldehyde & $x x$ & $x \times x$ & $x x x$ & $x$ & $x$ & \\
\hline 108 & Dimethylpyrazine (I) & & & & & & $x$ \\
\hline 108 & Dimethylpyrazine (II) & & & & & & $x$ \\
\hline 108 & 4-methylphenol & & & & $x x$ & & \\
\hline 122 & Ethylmethylpyrazine (I) & & & & & & $x$ \\
\hline 122 & Ethylmethylpyrazine (II) & & & & & & $x$ \\
\hline $122 b$ & Terpene compound & & $x$ & $x$ & & & \\
\hline 122 & Chlorobutanoic acid & & & & & & $x$ \\
\hline 126 & Dimethyltrisulfide & & & $x$ & & & \\
\hline 130 & Ethylhexanol & $x x$ & & & & & \\
\hline 136 & Limonene & $x$ & & & & $x x$ & \\
\hline 152 & Camphor & & & $x$ & & $x$ & \\
\hline
\end{tabular}

Roman numbers indicate different isomers.Semiquantitative data of peak areas calculated as relative abundances are shown as standardized indices: $x=0-33 \%, x x=34-66 \%$, and $x x x=$ $67-100 \%$. 
Limonene, butanone, acetic acid and camphor were the major compounds present in the headspace of the untreated sample of the SBV experiment (Table 3). In the case of treated soils, methylbenzene (toluene), dimethylbenzene (xylene), cyclohexanol and styrene showed the highest relative amounts. Cyclohexanone and benzaldehyde were major compounds in both SBV-treated and untreated soils. The high relative abundance of limonene in the control soil could be attributed to a contribution of the original vegetation at the soil collection site. ${ }^{[38]}$ In SBV-treated samples other compounds appear in higher amounts and the relative presence of limonene appears to be smaller.

It was observed that the gas phase composition of the SBV-treated samples to a large extent depended on the sampling depth. At the 20-cm level (Fig. 1A) the major volatile molecules were toluene, xylenes, styrene and cyclohexanol, whereas the most frequent compounds at $40 \mathrm{~cm}$ depth were nitrobutane and benzaldehyde, and compounds such as dimethylsulfide, dimethydisulphide and dimethytrisulfide were mainly present at $60 \mathrm{~cm}$ (Fig. 1B). The occurrence of sulphur compounds was not unexpected; a series of sulphurcontaining compounds have been detected by SPME in previous studies on composts mainly from sewage sludges. ${ }^{[39]}$ At a depth of $80 \mathrm{~cm}$ the main compounds detected were 2-butanone, acetic and propionic acids. The large influence observed on the molecular composition of volatile compounds in terms of sampling depth could be interpreted as a result of the effect of water saturated zones, which coincides with anaerobic activity.

A

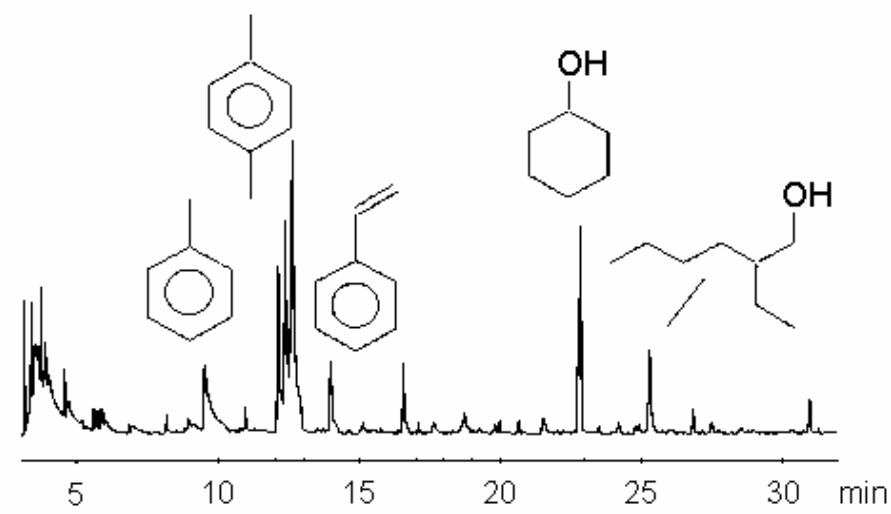

B

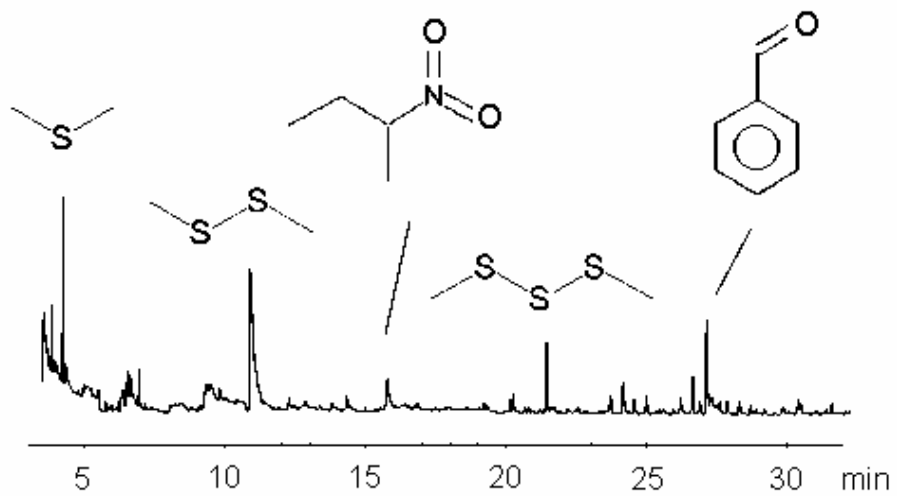

Figure 1. Current profiles of total ion from the atmosphere of soils treated with sugarbeet vinasses under a polyethylene sheet. A. At $20 \mathrm{~cm}$ soil depth: alkylbenzenes and aliphatic alcohols. B. At $60 \mathrm{~cm}$ soil depth: aromatic aldehydes, sulphur- and nitrogen compounds. 
The observed differences in the volatiles detected in each control soil indicate that the organic matter formerly present in the soil is an important factor in the headspace composition. Local vegetation and microbial metabolism, through their contribution to the formation of the soil organic matter, are largely responsible of the original volatile composition. This fact must be taken into account when studying the soil gas phase composition after amendment with organic materials. Otherwise, it would be difficult to explain which of the detected compounds are released by the organic amendments during their decomposition process in the soil, and which volatiles represent the contribution of the pre-existent soil organic matter.

Dimethyloctadiene, ocurring only in the PFW experiment (Table 2), is a volatile microbial product described in soils and ascribed to the metabolism of basidiomycetes. ${ }^{[40]}$ Terpene compounds have been also typically related to plant defence mechanisms against pests and pathogens. ${ }^{[35,41]}$ Nitriles (methylbutanenitrile), which have been previously reported as volatiles produced during biodisinfestation practices, ${ }^{[22]}$ were only found in SBV. In particular, potentially harmful products such as alkylbenzenes, including styrene as well as chlorinated compounds, are frequent volatile organic molecules from composts. ${ }^{[42]}$

\section{CONCLUSION}

Solid Phase Microextraction, combined with GC-MS, is a simple and fast fractionation technique useful for the identification of volatile compounds in soils. This technique was highly responsive to the nature and transformations of organic inputs applied to the soil. Characterization of soil samples from its volatile compounds composition is a useful approach to study the behaviour of organic amendments in the course of their decomposition in the soil. Also it could be used to analyze the possible relationships of the released volatiles in the control of pathogenic organisms in agricultural soils. A high number of compounds (more than thirty in the SBV experiment) have tentatively been identified in the soil gas phase. However, since SPME recovery is strongly dependant both on the extracted compound and on the sample matrix, its application for the quantitative characterization of soils from their volatile composition needs to be further studied. In particular, SPME has shown large differences in soil volatiles depending on the type of organic wastes applied and on the soil depth. Consequently, the determination of soil volatiles using SPME followed by GC-MS has a great potential to provide capital information on the chemical factors associated to the soil biologic activity in agro-ecosystems.

\section{ACKNOWLEDGEMENTS}

The authors wish to thank Spanish Inter-Ministerial Commission of Science and Technology (CICyT) for the research project CTM2006-07309, Comunidad de Madrid for program S505/AGR-0312, and the Spanish Institute for Agriculture and Food Research and Technology (INIA) for the projects AT06-006-C7-4 and RTA2007-00099-00-00. Dr. Ana Piedra Buena has been contracted by the CCMA-CSIC via the I3P Program, which is funded by the European Social Fund. 


\section{REFERENCES}

[1] Arthur, C. L.; Pawliszyn, J. Solid-Phase Microextraction with thermal-desorption using fused-silica optical fibers. Anal. Chem. 1990, 62, 2145-2148.

[2] Pawliszyn, J. Solid Phase Microextraction-Theory and Practice; Wiley-VCH: New York, 1997.

[3] Pawliszyn, J. Applications of Solid Phase Microextraction; RSC: Cornwall, UK, 1999.

[4] Pastore, P.; Favaro, G.; Badocco, D.; Lavagnini, I. Headspace solid phase micro extraction GC-ECD determination of volatile organic chlorinated hydrocarbons in soils. Ann. Chim. - Rome 2005, 95, 741-756.

[5] Bravo-Linares, C. M.; Mudge, S. M. Analysis of volatile organic compounds (VOCs) in sediments using in situ SPME sampling. J. Environ. Monit. 2007, 9, 411-418.

[6] Banar, M.; Ozkan, A.; Vardar, C. Characterization of an urban landfill soil by using physicochemical analysis and solid phase microextraction (SPME)-GC/MS. Environ. Monit. Assess. 2007, 127, 337-351.

[7] Bello, A.; Escuer, M.; Sanz, R.; López, J. A.; Guirao, P. Biofumigación, nematodos y bromuro de metilo en cultivo de pimiento. In Posibilidad de Alternativas Viables al Bromuro de Metilo en Pimiento de Invernadero; Publicaciones de la CMAA-Región de Murcia; Murcia, Spain, 1997; Jornadas y Congresos 11, 67-108.

[8] Bello, A., Díaz Viruliche, L., López-Pérez, J. A., García-Álvarez, A. Evaluación de nuevos biofumigantes. In Biofumigación en Agricultura Extensiva de Regadio; Bello, A., López-Pérez, J. A., García-Álvarez, A., Eds.; Fundación Ruralcaja AlicanteEditorial Mundi Prensa: Alicante, Spain, 2003; 371-466.

[9] García Álvarez, A., Díez-Rojo, M. A., López-Pérez, J. A., Bello, A. Materia orgánica, biofumigación y manejo de organismos del suelo patógenos de vegetales. In Conocimientos, Técnicas y Productos para la Agricultura y la Ganadería Ecológica; Labrador, J., Ed.; SEAE: Valencia, Spain, 2004; 71-76.

[10] López-Pérez, J. A.; Roubtsova, T.; Ploeg, A. Effect of three plant residues and chicken manure used as biofumigants at three temperatures on Meloidogyne incognita infestation of tomato in greenhouse experiments. J. Nematol. 2005, 37, 489-494.

[11] Pierson, C. L.; Sams, C. E.; Deyfon, D. E.; Charron, C. S. Time and temperature effects on degradation of isothiocyanates in biofumigation systems. Hortscience 2006, 41, 504.

[12] MBTOC. Report of the Methyl Bromide Technical Options Committee; UNEP: Nairobi, Kenya, 2002.

[13] MBTOC. 2006 MBTOC Assessment Report; UNEP; Nairobi, Kenya, 2007.

[14] PiedraBuena, A.; García-Álvarez, A.; Díez-Rojo, M. A.; Bello, A. Use of crop residues for the control of Meloidogyne incognita in laboratory conditions. Pest Manag. Sci. 2006, 62, 919-926.

[15] Kirkegaard, J. A.; Robertson, M. J.; Hamblin, P.; Sprague, S. J. Effect of blackleg and sclerotinia stem rot on canola yield in the high rainfall zone of southern New South Wales, Australia. Aust. J. Agric. Res. 2006, 57, 201-212.

[16] Yulianti, T.; Sivasithamparam, K.; Turner, D. W. Response of different forms of propagules of Rhizoctonia solani AG2-1 (ZG5) exposed to the volatiles produced in soil amended with green manures. Ann. Appl. Biol. 2006, 148, 105-111.

[17] Bello, A.; Arias, M.; López-Pérez, J. A.; García-Álvarez, A.; Fresno, J.; Escuer, M.; Arcos, S. C.; Lacasa, A.; Sanz, R.; Gómez, P.; Díez-Rojo, M. A.; Piedra Buena, A.; Goitía, C.; de la Horra, J. L.; Martínez, C. Biofumigation, fallow, and nematode management in vineyard replant. Nematropica 2004, 34, 53-64. 
[18] Lazzeri, L.; Baruzzi, G.; Malaguti, L.; Antoniacci, L. Replacing methyl bromide in annual strawberry production with glucosinolate-containing green manure crops. Pest Manag. Sci. 2003, 59, 983-990.

[19] Lazzeri, L., Leoni, O., Bernardi, R., Patalano, G., Palmieri, S. Vegetable biocidal pellets for biofumigation and fertilisation. Bull. OILB/SROP 2004a, 27, $25 \mathrm{p}$.

[20] Lazzeri, L.; Leoni, O.; Manici, L. M. Biocidal plant dried pellets for biofumigation. Ind. Crop. Prod. 2004b, 20, 59-65.

[21] Matthiessen, J. N., Shackleton, M. A. Biofumigation: environmental impacts on the biological activity of diverse pure and plant-derived isothiocyanates. Pest Manag. Sci. 2005, 61, 1043-1051.

[22] Mattner, S. W.; Gregorio, R.; Ren, Y. L.; Hyland, T. W.; Gounder, R. K. Sarwar, M. Porter, I. J. Application techniques influence the efficacy of ethanedinitrile $\left(\mathrm{C}_{2} \mathrm{~N}_{2}\right)$ for soil disinfestations. In Abstracts, Annual International Research Conference on Methyl Bromide Alternatives and Emission Reductions, San Diego, California, Nov 3-6, 2003; 1271-1274.

[23] Soria, A.C.; Martínez-Castro, I.; Sanz, J. Analysis of volatile composition of honey by solid phase microextraction and gas chromatography-mass spectrometry. J. Sep. Sci. 2003, 26, 793-801.

[24] National Institute of Standards and Technology (NIST). NIST/EPA/NIH Mass Spectral Database, Standard Reference Database $1 a$ and the NIST Mass Spectral Search Program; version 1a; Gaithersburg, MD, 1995.

[25] Wiley, J. Wiley Registry of Mass Spectral Data, 8th Ed.; Wiley: Chichester, UK, 2005.

[26] Yoon, I. K.; Kim, C. N.; Park, C. H. Optimum operating conditions for the removal of volatile organic compounds in a compost-packed biofilter. Korean J. Chem. Eng. 2002, 19, 954-959.

[27] Kurose, K.; Okamura, D.; Yatagai, M. Composition of the essential oils from the leaves of nine Pinus species and the cones of three of Pinus species. Flavour Fragr. J. 2007, $22,10-20$.

[28] Lin, C.; Owen, S. M.; Peñuelas, J. Volatile organic compounds in the roots and rhizosphere of Pinus spp. Soil Biol. Biochem. 2007, 39, 951-960.

[29] Nikolić, B.; Ristić, M.; Bojović, S.; Marin, P.D. Variability of the needle essential oils of Pinus heldreichii from different populations in Montenegro and Serbia, Chem. Biodiv. 2007, 4, 905-916.

[30] Nikolić, B.; Ristić, M.; Bojović, S.; Marin, P.D. Variability of the needle essential oils of Pinus peuce from different populations in Montenegro and Serbia. Chem. Biodiv. 2008, 5, 1377-1388.

[31] Semiz, G.; Heijari, J.; Isik, K.; Holopainen, J. K. Variation in needle terpenoids among Pinus sylvestris L. (Pinaceae) provenances from Turkey. Biochem. Syst. Ecol. 2007, 35, 652-661.

[32] Judzentiene, A.; Kupcinskiene, E. Chemical composition on essential oils from needles of Pinus sylvestris L. fround (?) in Northern Lithuania. J. Essent. Oil Res. 2008, 20, 2629.

[33] Pyle, N. Norm Pyle's Hops FAQ, 1995. http://www.realbeer.com/hops/FAQ.html (accessed Nov 2008).

[34] Kishimoto, T.; Wanikawa, A.; Kagami, N.; Kawatsura, K. Analysis of hop-derived terpenoids in beer and evaluation of their behaviour using the stir bar-sorptive extraction method with GC-MS. J. Agric. Food Chem. 2005, 53, 4701-4707.

[35] Rasmann, S.; Köllner, T. G.; Degenhardt, J.; Hiltpold, I.; Toepfer, S.; Kuhlmann, U.; Gershenzon, J.; Turlings, T. C. J. Recruitment of entomopathogenic nematodes by insect-damaged maize roots. Nature 2005, 434, 732-737. 
[36] Favaro, G.; Magno, F.; Boaretto, A.; Bailoni, L.; Mantovani, R. Traceability of Asiago mountain cheese: a rapid, low-cost analytical procedure for its identification based on Solid-Phase Microextraction. J. Dairy Sci. 2005, 88, 3426-3434.

[37] Viuda-Martos, M.; Ruíz-Navajas, Y.; Fernández-López, J.; Pérez-Álvarez, J. A. Chemical composition of the essential oils obtained from some spices widely used in Mediterranean region. Acta Chim. Slov. 2007, 54, 921-926.

[38] Filipsson, F.; Bard, J.; Karlsson, S. Concise International Chemical Assessment Document 5: Limonene; UN Environment Programme-ILO- WHO: Geneva, Switzerland, 1998; 1-36.

[39] Kim, H.; McConnell, L. L.; Millner, P. Comparison of odorous volatile compounds from fourteen different commercial composts using solid-phase microextraction. Trans. ASAE 2005, 48, 315-320.

[40] Juttner, F. Monoterpenes and microbial metabolites in the soil. Environ. Pollut. 1990, 68, 377-382.

[41] Gershenzon, J.; Dudareva, N. The function of natural terpene products in the natural world. Nature Chem. Biol. 2007, 3, 408-414.

[42] Yoon, I. K.; Kim, C. N.; Park, C. H. Optimum operating conditions for the removal of volatile organic compounds in a compost-packed biofilter. Korean J. Chem. Eng. 2002, 19, 954-959. 